\title{
Optimization of HR Education and Training for Village Fund Managers
}

\author{
Faizal Marzuki ${ }^{1}$, Alfaith S. Manggabarani ${ }^{2}$, Munasiron Miftah
}

\section{Info Artikel}

Sejarah Artikel:

Diterima: 18 Juni 2020

Direvisi: 22 Juli 2020

Dipublikasikan: Agustus 2020

e-ISSN: 2620-3081

p-ISSN: $1411-2744$

DOI:10.21009/jtp.v22i2. 16398

\begin{abstract}
This study aims to describe the optimization of village fund processing to realize the dsa mandini community in the Cileles sub-district of Lebak Banten. The research method used is descriptive with a qualitative approach. The result that will be achieved is to create the concept of a village head apparatus who has a strong will to build his village into a mandini village. The main factor is building human resources and utilizing a friendly and hard-working community culture in people's lives. This is a capital that can be developed by the village head in building his village in mutual cooperation. From the results of this study it was concluded that the head of the village in utilizing village funds, could not be implemented optimally by the village, because the village planning proposal had not been fully approved by the district government which made changes to the village proposal, the change was not necessarily in accordance with the needs of the development his village, as a result village must accept changes even if it is not as expected by the village. Such a change certainly does not allow the village to respond quickly, resulting in delays in receiving village funds and automatically the village development program will be too late. besides the lack of resources $(H R)$ that have the skills needed by the village to go to the village of Mandani.
\end{abstract}

Keyword: training, village fund processing, village community, cileles lebak banten village fund

(C) 2020 PPS Universitas Negeri Jakarta

\section{INTRODUCTION}

Village fund allocation (ADD) aims to realize village governments that can manage regional development based on their own budget priorities. This is in accordance with the third point of the development agenda in Regulation No. 2 of 2015 concerning the 2015-2019 RPJMN which is to realize new ideals by developing Indonesia from the periphery by strengthening regions and villages within the framework of the unitary state of the Republic of Indonesia. The amount of the village fund budget every year always increases. In 2015 the village fund budget reached 20.7 trillion rupiah. In $2016 \mathrm{v}$ reached 47.6 trillion rupiah. And in 2017 the village fund budget reaches 81 trillion rupiah. This causes the location of village funds (ADD) in each village to increase.

In the implementation of the ADD policy which is carried out in all villages in Indonesia, it will certainly give different results between one village and another. Basically, the success of this policy can be caused by several factors. The most important factor is how much the village apparatus is prepared, and also how much is the level of community participation that contributes to the process of managing village fund allocations.

The principle of managing village funds places more emphasis on the three principles of good governance, namely accountability,

\footnotetext{
${ }^{1}$ Faisal Marzuki. Universitas Pembangunan Nasional Veteran Jakarta, email: faisal@upnvj.ac.id

2 Alfaith S. Manggabarani, Universitas Pembangunan Nasional Veteran Jakarta

${ }^{3}$ Munasiron Miftah, Universitas Pembangunan Nasional Veteran Jakarta
} 
transparency, and participation. It is hoped that this research can provide a clear picture of the process of managing village fund allocations starting from the planning, implementation to accountability and reporting stages, in accordance with applicable regulations. It is also expected to be able to describe and explain the problems in the management of ADD and provide solutions to village officials as managers. It is hoped that this research will have a positive impact on the management of ADD that is effective and efficient, so that it can develop and prosper its own village into an independent and mandani village.

The village head of Margamulya also stated that the obstacles faced in managing ADD were related to the discipline of the DSA instruments at work. The preparation of year-end reports is still often late, and this causes a delay in the acceptance and search for ADD at the next stage or the next fiscal year. in addition, village officials are still constrained by the facilities and infrastructure of each village, village administration that is lacking in order and financial administration which is still often ignored. The low level of knowledge education, and experiencing social problems such as natural disasters such as (floods, landslides), damaged public facilities and agriculture are also reasons why researchers choose villages as research objects.

The village is one of the structures of the government which is at the bottom position is the spearhead of development in Indonesia, where the majority of the population works as farmers, ranchers and small businesses, and has a relatively low level of education. The village is the government closest to the community in carrying out public services, public services, and empowerment (Hehamahua, 2015) because the majority of Indonesia's population lives in the village. Village fund allocation (ADD) is funds allocated by the central government through regencies or cities, which are sourced from the central and regional financial balance funds received by regencies or cities (PP No. 72 of 2015 Article 1 Paragraph 11). Village funds sourced from the National Budget are a form of state recognition to villages. The share of the central and regional balance funds received by the district or city for this village is at least $10 \%$ of the proportional distribution for each village (Warsono 2014).

The management cycle based on village laws includes: 1) preparation of plans; 2) Village Musrenbags involving the village government, BPD, and community groups starting with the hamlet level to the village level; 3) The determination of the plan here is a guideline for the budget of the village budget (APB) income; 4) determination of village APB; 5) implementation of development, involving all communities in a self-managed manner; 6) accountability of village crossers is obliged to submit reports in village development meetings; 7) utilization and maintenance (Law No. 6 of 2014). Village fund management includes three important activities, namely: implementation and accountability, referred to as P3.

\section{RESEARCH METHODS}

This study was included in a qualitative descriptive study. Descriptive study (descriptive study), is intended to explain aspects that are relevant to the observed phenomenon. This study helps researchers to explain the characteristics of the subjects studied, examine several aspects of ADD management phenomena in realizing good governance, and offer ideas / models for further testing or research, using case study methods, namely detailed observation of objects or person. Primary data in this study were obtained through direct interviews with competent parties in the management of ADD in the village namely the village head while for secondary data obtained through reference studies and documents related to regulations governing the organization of the regional apparatus, previous research, library research, internet, journals, records, pictures, notes and other references relating to this research. 
Figure 1. Flowchart planning stage ADD

Data collection techniques used in research to realize data and information that is valid and accurate, namely a. The questionnaire is the main data (primary data) in the form of a list of questions submitted by researchers filled in by respondents in order to obtain accurate data, b. Interview is a data collection technique that is in survey mode that uses oral questions to research subjects. The researcher conducts question and answer questions and direct and in-depth conversations (indepth interviews) to informants who are competent in managing ADD, c. Observations were made by directly observing the focus of the research, namely the management of ADD in realizing good governance and coming directly to the research location in the villages of Cileles sub-district and Cileles sub-district offices, $d$. documentation, namely the collection of data obtained through a study of written records and documents.

\begin{tabular}{|c|c|c|c|}
\hline $\begin{array}{l}\text { accountabili } \\
\text { ty }\end{array}$ & Transparency & Participation & Activity \\
\hline Planning & $\begin{array}{ll}\text { 1. } & \text { Village } \\
\text { Medium Term } \\
\text { Development } \\
\text { Plan } \\
\text { 2. RKP Village } \\
\text { 3. } & \text { APB Village } \\
\text { 4. } & \text { RPD / Pendes }\end{array}$ & $\begin{array}{l}\text { Information } \\
\text { board or } \\
\text { mass media } \\
\text { The } \\
\text { provisions of } \\
\text { the delivery } \\
\text { of } \\
\text { permendagri } \\
\text { information } \\
\text { No. } 114 \mathrm{~T} \\
2014\end{array}$ & $\begin{array}{l}\text { Musdes } \\
\text { orusenbangde } \\
\text { s Law No. } 6 \\
\text { T } 2014 \\
\text { Minister of } \\
\text { Domestic } \\
\text { Affairs No. } \\
114 \text { T } 2014\end{array}$ \\
\hline $\begin{array}{l}\text { Implementat } \\
\text { ion }\end{array}$ & 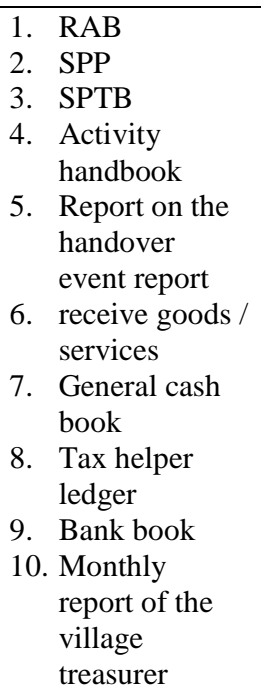 & $\begin{array}{l}\text { ivity or media } \\
\text { information } \\
\text { boar } \\
\text { ing of delivery } \\
\text { of information }\end{array}$ & 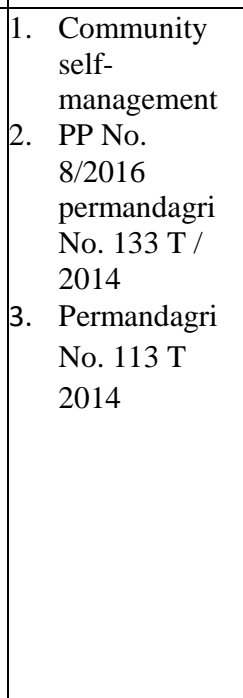 \\
\hline Liability & $\begin{array}{l}\text { 1. Report on the } \\
\text { realization of } \\
\text { APBD Smt I } \\
\text { 2. Report on the } \\
\text { implementatio } \\
\text { n of the village } \\
\text { budget for the } \\
\text { last semester } \\
\text { 3. Accountability } \\
\text { report on the } \\
\text { realization of } \\
\text { village APB } \\
\text { implementatio } \\
\text { n } \\
\text { 4. Report on } \\
\text { village } \\
\text { property assets } \\
\text { 5. Report on } \\
\text { government } \\
\text { and local } \\
\text { government } \\
\text { programs that } \\
\text { enter the } \\
\text { village } \\
\text { 6. LPPD }\end{array}$ & $\begin{array}{l}\text { Information } \\
\text { boards or } \\
\text { mass media }\end{array}$ & $\begin{array}{l}\text { Timeliness of } \\
\text { information } \\
\text { delivery } \\
\text { Permandagri } \\
\text { No. } 113 \text { of } 2014\end{array}$ \\
\hline
\end{tabular}

Table 1. indicator interview guide Stage indicators
The steps that must be taken by the village apparatus in optimizing the management of village fund allocation in 
realizing the mandani village are as follows: a. consider the fixed income needs of the village head and village apparatus, b. consider the population of the village, the poverty rate of the village, the area of the village, and the degree of geographical difficulty of the village, c. increase the implementation of village government in carrying out government services, development and community authority, d. improve the ability of community institutions in the village in planning, implementing and participating in development trials in accordance with village potentials, e. increase income distribution, employment opportunities and business opportunities for rural communities, $f$. encourage increased self-help and community cooperation in the village

\section{RESEARCH RESULTS AND DISCUSSION}

Data analysis in qualitative research is carried out at the time of data collection and after the data collection is completed within a certain period. Data analysis techniques used in this study are the miles and huberman models (Prastowo 2012; 2014) where data and qualitative analysis is an analysis process that consists of three activities that occur simultaneously, namely data reduction, data presentation and drawing conclusions or verification or verification. Data reduction means to summarize, choose the main things that focus on important things, look for themes and patterns.

In the planning of village fund allocation (ADD) in the district of Cileles, the district of Lebak Banten, which is allocated by the sub-district government to the dea in the district in Cileles, is carried out to achieve the goals set for each village. And the process of achieving this goal in the management of ADD every year can be carried out properly where the physical and physical development process can be carried out by the village government in accordance with the needs of the community, although not all community needs can be met with the help of ADD, but in responding to this the village government does the selection of community priority development that must be prioritized through deliberations or musrenbangdes held annually to increase the allocation of ADD. In this way, the village government can carry out the process of physical and non-physical development gradually to create prosperity for the community.

\section{CONCLUSION}

ADD management process, in general ADD can be well received and utilized by the community of Cileles sub-district. Although these funds are still limited, they have been able to accelerate village development. Most people in the village said that the ADD policy was felt to have been transparent every year and its use was democratic based on what was done in the village musrenbang. According to the statement of the Cileles sub-district head to develop the village, the villagers' needs will continue. This can be seen from the many community proposals that are submitted every year in the village development planning meeting.

Every community participation is given to solve a problem and control the running of the government in the village. During this time community participation has been built by a sense of togetherness and a high shortage of fellow villagers. As a village which is located in Cileles sub-district, in particular, it still cultivates the values of togetherness and mutual cooperation between the community and the village government in determining the priorities of village development that will create prosperity for the community.

\section{REFERENCES}

Keown AJ, Martin JD, Petty JW, Scott DF (2005). Financial Management $10^{\text {th }}$ edition. Prentice Hall International Editions. Singapore.

Kurbiasih, Agustina; Hermanto Siregar; Roy Sembel; dan Noer Azam Achasni. (2011). "corporate Devidend Policy in an Emerging Market: Evidence from Indonesia Stock Exchange (IDX) 2001-2008". International Research Journal of Finance and Economics. 
Mondy, Wayne. (2008) . Human Resource Management, Person Education, Inc. Nem Jersey

Nadeak, Supranto. (2011). "Faktor-faktor yang Mempengaruhi Kinerja Konsultan Kecamatan pada PNPM-PISEW Propinsi Sumatera Utara". Tesis. Program Magister Manajemen. Universitas Mercu Buana. Jakarta

Sunarcahya, Putu. (2008). "Analisis Pengaruh Faktor-faktor Inddividu dan Iklim Organisasi terhadapt Kinerja Karyawan”. Tesis. Program Magister Manajemen. Universitas Diponegoro. Semarang. 